\title{
On the use of Monetary and Macroprudential Policies for Small Open Economies
}


On the use of Monetary and Macroprudential Policies for Small Open Economies

F. Gulcin Ozkan and D. Filiz Unsal 


\title{
IMF Working Paper
}

\author{
Strategy, Policy, and Review Department
}

\section{On the use of Monetary and Macroprudential Policies for Small Open Economies ${ }^{1}$ Prepared by F. Gulcin Ozkan and D. Filiz Unsal}

Authorized for distribution by Catherine Pattillo

June 2014

\section{This Working Paper should not be reported as representing the views of the IMF.} The views expressed in this Working Paper are those of the author(s) and do not necessarily represent those of the IMF or IMF policy. Working Papers describe research in progress by the author(s) and are published to elicit comments and to further debate.

\begin{abstract}
We explore optimal monetary and macroprudential policy rules for a small open economy. Delegating 'lean against the wind' squarely to macroprudential policy provides a more robust policy mix to shock uncertainty - (i) if macroprudential measures exist, there are no significant welfare gains from monetary policy reacting to credit growth under a financial shock; and (ii) monetary responses to financial markets could generate bigger welfare losses than macroprudential responses under different shocks. The source of outstanding liabilities also plays a role in the choice of policy instrumentmacroprudential policies are particularly effective for emerging markets where foreign borrowing is sizeable.
\end{abstract}

JEL Classification Numbers: E5, F3, F4

Keywords: Financial instability; monetary policy; macroprudential measures; emerging Author's E-Mail Address: gulcin.ozkan@york.ac.uk; dunsal@,imf.org

\footnotetext{
${ }^{1}$ We would like to thank C. Adams, Y. Aksoy, P. Basu, D. Cobham, M. Ellison, L. Evans, M. Graffoli, R. Gurkaynak, M. Miller, P. Minford, D. Sandri, P. Sinclair, C. Pattillo, J. Pearlman, R. Portillo, M. Wickens, S. Wright, T. Yates and participants at MMF Annual Conference, Dublin, 6-8 Sept. 2012; "Macroprudential Regulation" Conference at Loughborough University, 18-19 Sep. 2012, and Seminar at the BoE, 17 July 2013 for comments and suggestions.
} 


\section{Content Page}

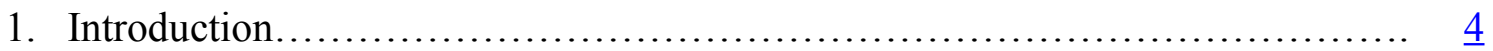

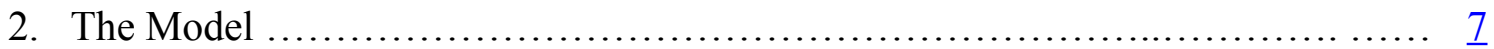

2.1 Households.................................................................

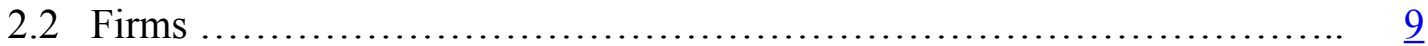

2.2.1 Production firms ..................................................

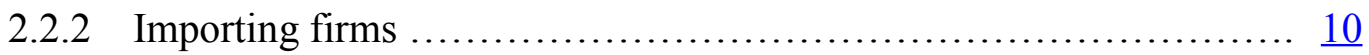

2.2.3 Unfinished Capital Producing Firms............................ 10

2.3 Entrepreneurs ...................................................... $\frac{11}{11}$

2.3.1 Only Foreign Borrowing …..................................... 11

2.3.2 Only Domestic Borrowing....................................

2.3.3 Both Foreign and Domestic Borrowing.......................... 13

2.4 Financial Intermediaries and Macroprudential Policy..................... 14

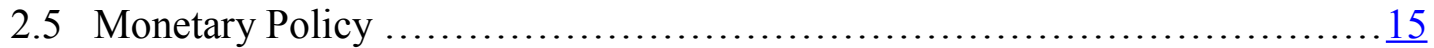

3. Model Parametrization ......................................................

4. Model Dynamics............................................................

4.1 Monetary and Macroprudential Policy ................................. 16

4.2 Should Monetary Policy Lean Against the Wind?.......................... 17

5. Optimal Policy and Welfare Evaluation .................................... 19

5.1 Optimal Policy and Welfare Evaluation ................................ 19

5.2 The role of the Borrowing Source ...................................... 21

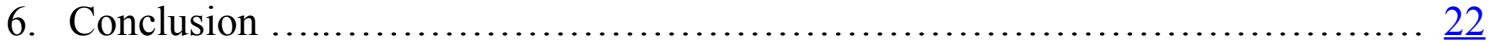

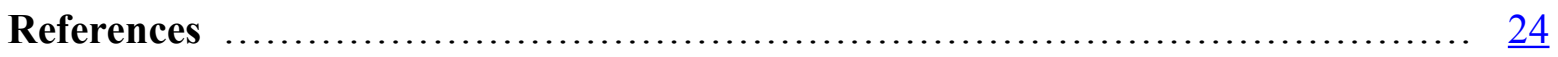

\section{List of tables}

1. Parameter Values for Consumption, and Production Sectors ................. $\underline{27}$

2. Parameters of the Policy Rules and the Macroprudential Instrument ............. $\underline{28}$

3. Welfare Results for Alternative Policies in Response to a Financial Shock ...... $\underline{28}$

4. The Optimized Coeficients of Monetary and Macroprudential Policy Rules in $\underline{29}$ Response to a Financial Shock

5. Welfare Results for Alternative Policies in Response to a Productivity Shock ... $\underline{29}$

6. The Optimized Coefficients of Monetary and Macroprudential Policy Rules in $\underline{30}$ Response to a Productivity Shock

7. The Optimized Responses to Credit Markets under a Financial Shock: Sources $\underline{30}$ of Borrowing

\section{List of Figures}

1. A Negative Financial Shock: Taylor Rule and Macroprudential Policy ............ 31

2. A Negative Financial Shock: Taylor Rule and Taylor Rule with Credit Growth .... $\underline{32}$

3. A Negative Productivity Shock: Taylor Rule and Macroprudential Policy …....... $\underline{33}$

4. A Negative Productivity Shock: Taylor Rule and Taylor rule with Credit Growth... $\underline{34}$ 


\section{Introduction}

The recent global financial crisis, widely viewed as the worst since the Great Depression of the 1930s, has forced a serious rethink of how monetary policy should be conducted. A key feature of the 2008-2009 crisis is that it was preceded by a build up of financial vulnerabilities, particularly in housing and credit markets, in many economies against the backdrop of low inflation and robust economic activity. The role of monetary policy in contributing to the build up of the asset price bubble and its limited ability to effectively respond to the bubble's collapse have come under close scrutiny since the onset of the crisis in 2008 (see, for example, Cecchetti, 2008 and Taylor, 2008).

Whether monetary policy should respond to the build up of asset-price bubbles or to their collapse is not a new phenomenon. There had been an active debate on this issue long before the recent global financial crisis. Notwithstanding some prominent counter-arguments, this so called 'lean versus clean' debate had led to a general agreement that monetary policy should react to asset market developments only insofar as they provide useful information for forecasting the variables in the objective function of the central bank. Central to this policy prescription was the understanding that potential costs of cleaning up after a bubble bursts are not large, a notion seriously undermined by the experiences of crisis inflicted countries since 2008.

It is now widely recognized that price stability, the primary focus of monetary policy in the pre-crisis period, is not sufficient for financial stability. A clear consensus has emerged on the need for policy to react to asset market misalignments as a way of preventing financial instability and adverse macroeconomic outcomes. ${ }^{1}$ There is, however, an on-going debate on the choice of policy instruments to be used for that purpose. The limits of using the policy rate to trade-off multiple goals - macroeconomic and financial stability- are well-known. Hence, incorporating financial stability into macroeconomic policy objectives may require looking beyond the traditional policy instruments of central banks to adopt other tools such as macroprudential measures.

Underlying the prescription of such policy measures is the notion that financial markets are inherently procyclical. That is, during boom times, perceived risk declines; asset prices increase; and lending and leverage become mutually reinforcing. Firms increase new borrowing, and the rise in domestic inflation reduces the real debt burden for leveraged households, leading to an increase in output and inflation. The opposite happens during a bust phase: a vicious cycle can arise between deleveraging, asset sales, and the real economy. In principle, macroprudential measures could address procyclicality of financial markets and reduce the

\footnotetext{
${ }^{1}$ See Mishkin (2011).
} 
amplitude of the boom-bust cycles by design.

But how is responding to financial developments through the policy rate different from responding through a macroprudential instrument? Although both instruments affect aggregate demand and supply as well as financial conditions in similar ways, they are not perfect substitutes. First, the policy rate may be 'too blunt' an instrument, as it impacts all lending activities regardless of whether they represent a risk to stability of the economy. In contrast, macroprudential regulations can be aimed specifically at markets in which the risk of financial stability is believed to be excessive. Second, in economies with open financial accounts, an increase in the interest rate is likely to have only a limited impact on credit expansion if firms can borrow at a lower rate abroad. Third, interest rate movements aiming to ensure financial stability could be inconsistent with those required to achieve macroeconomic stability, and that discrepancy could destabilize inflation and even risk de-anchoring inflation expectations (see, for example, Borio and Lowe, 2002).

The literature on the use of macroprudential instruments has been expanding on two fronts. First line of research has focused on the impact of macroprudential measures in managing negative externalities that arise out of agents not internalizing the effect of their individual decisions on financial instability. For example, Korinek (2009), Jeanne and Korinek (2010), Bianchi (2011) and Bianchi and Mendoza (2010) focus on overborrowing and consequent externalities. In these papers, regulations induce agents to internalize the consequences of their actions and thereby increase macroeconomic stability. However, overborrowing is a model-specific feature. For example, Benigno et al. (2013) find that in normal times, underborrowing is much more likely to emerge rather than overborrowing. Our paper fits into the second strand of research which analyzes the potential role of macroprudential regulations in equilibrium models where monetary policy has a non-trivial role in stabilizing the economy after a shock (see, for example, Angeloni and Faia, 2009, Angelini et al., 2010, Kannan et al., 2012, Unsal, 2013, Quint and Rabanal, 2014, and Roldos and Medina, 2014).

We utilize an open economy New Keynesian dynamic stochastic general equilibrium (DSGE) model, featuring the financial frictions. The model draws on elements of models by Bernanke et al.(1999), Gertler et al. (2007), Kannan et al. (2012), and particularly Ozkan and Unsal (2012) and Unsal (2013). In our framework, a preemptive response through monetary policy (Taylor rule) entails a reaction to a financial market variable (nominal credit growth). Macroprudential policy, on the other hand, gives rise to higher costs for financial intermediaries that are passed onto borrowers in the form of higher lending rates - what we call a 'regulation premium'. The regulation premium is defined as a rule which responds to nominal credit growth. This set up captures the notion that such measures make it harder for firms to borrow during boom times, and hence make the subsequent bust less dramatic, 
dampening the scale of fluctuations.

Our paper has three main contributions. First, in contrast to the great majority of the existing work on the interaction between monetary and macroprudential policies, we adopt an open economy framework. ${ }^{2}$ This enables us to consider a realistic financial crisis scenario brought by a sudden reversal of capital inflows; and to take into account external channels, including the exchange rate, when analyzing the implications of alternative policy regimes on a wide range of macroeconomic variables. Second, utilizing our open economy setting, we examine the role of the sources of borrowing (domestic versus foreign) on the desirability of responding to financial market developments through monetary and macroprudential policies, an issue which has not been explored in the existing literature. This has implications for the relative effectiveness and the impact of monetary and macroprudential policies in promoting financial stability in emerging markets where foreign borrowing is typically sizeable.

The third contribution of this paper lies in providing some insights about a policy mix that is robust to real-time shock uncertainty. Required response (or lack thereof) to changes in financial conditions may vary depening on the source of the shock. However, shocks are generally not observed by the policymakers in real-time. Therefore, systematic responses to financial market developments through monetary or macroprudential tools need to perform well even when policymakers have imperfect knowledge about the true nature of the shock. In this paper, by assessing performances of several policy options under two different shocks, we derive operational suggestions regarding a robust use of monetary and macroprudential tools.

Our main findings are as follows. Responding to credit growth through the monetary instrument improves macroeconomic stability and hence welfare following a (negative) financial shock. However, in the presence of macroprudential measures, there are no significant welfare gains from monetary policy also reacting to credit growth above and beyond its response to output gap and inflation. Moreover, welfare costs of responding to credit growth in the aftermath of a productivity shock are much higher if the response is through the

\footnotetext{
${ }^{2}$ Unsal (2013) adopts an open economy framework where monetary and macroprudential rules are modelled to have different objectives - monetary policy does not respond to changes in financial market developments. In contrast, in this paper we examine whether responding to financial market developments through monetary or macroprudential tools provides the best welfare outcome. Quint and Rabanal (2014) adopts a framework with two countries of equal size to investigate the role of macroprudential policies in the Euro area. Medina and Roldos (2014) also use a small open economy framework to analyze the interaction between monetary and macroprudential policies. However, unlike in our paper, they do not explicitly model the foreign economy, which may raise questions about the generality of the results. For example, they analyze the interaction between monetary and macroprudential policies in the face of a decline in the foreign interest rate which, in their model, does not have any implications for foreign income of for foreign prices which are among the major determinants of exports and exchange rate for the domestic econnomy.
} 
policy rate than through the macroprudential instrument. This implies that a policy mix that delegates "lean against the wind" squarely to macroprudential policy would be more robust to shock uncertainty. We also find that the source of borrowing is an important determinant of desirability of alternative policies; the greater the size of foreign borrowing the greater the benefits from macroprudential measures. This is because, in contrast to the policy rate, macroprudential instrument can directly influence the cost of credit when the source of borrowing is external. It, therefore, follows that emerging economies where foreign borrowing is typically sizeable, are likely to find macroprudential policies particularly effective in promoting financial stability.

The remainder of the paper is organized as follows. Section 2 sets-out the structure of our model by describing household, firm and entrepreneurial behavior with a special emphasis on financial intermediaries and macroprudential policies. Section 3 describes the solution and the calibration of the model. Section 4 presents impulse responses to financial and productivity shocks under alternative monetary and macroprudential policy regimes. Section 5 presents a quantitative welfare analysis of monetary and macroprudential policies and computes welfare maximizing reaction and/or intervention through monetary and macroprudential policies. Finally, Section 6 provides the concluding remarks.

\section{The model}

Our framework is a DSGE model of an emerging economy that features the financial accelerator a la Bernanke et al. (1999). Following, Gali and Monacelli (2002) and De Paoli (2009) among many others, we derive the dynamics of small open economy (SOE) as a limiting case of a two country model where the size of the SOE is negligible relative to the size of the rest of the world (ROW). The economy is populated by households, firms, entrepreneurs, financial intermediaries and a monetary authority.

\subsection{Households}

Households receive utility from consumption and provide labor to the production firms. They participate in domestic and (incomplete) international financial markets. The households own the firms in the economy and therefore receive profits from these firms. An infinitely lived representative household seeks to maximize:

$$
E_{0} \sum_{t=0}^{\infty} \beta^{t} \frac{1}{1-\sigma}\left(C_{t}-\frac{H_{t}^{1+\varphi}}{1+\varphi}\right)^{1-\sigma}
$$


where $C_{t}$ is a composite consumption index, $H_{t}$ is hours of work, $E_{t}$ is the mathematical expectation conditional upon information available at $t, \beta$ is the representative consumer's subjective discount factor where $0<\beta<1, \sigma>0$ is the inverse of the intertemporal elasticity of substitution and $\varphi>0$ is the inverse elasticity of labour supply. Our specification for household's utility allows for Greenwood, Hercowitz and Huffman (GHH, 1988) preferences over hours, which eliminates wealth effects from labor supply.

The composite consumption index, $C_{t}$, is given by:

$$
C_{t}=\left[(1-\alpha)^{\frac{1}{\gamma}} C_{H, t}^{(\gamma-1) / \gamma}+(\alpha)^{\frac{1}{\gamma}} C_{M, t}^{(\gamma-1) / \gamma}\right]^{\gamma /(\gamma-1)}
$$

where $\gamma>0$ is the elasticity of substitution between domestic and imported (foreign goods), and $0<\alpha<1$ denotes the weight of imported goods in domestic consumption basket. $C_{H, t}=\left[\int_{0}^{1} C_{H, t}(j)^{(\lambda-1) / \lambda} d j\right]^{\lambda /(\lambda-1)}$ and $C_{M, t}=\left[\int_{0}^{1} C_{M, t}(j)^{(\lambda-1) / \lambda} d j\right]^{\lambda /(\lambda-1)}$ are consumption of domestic and foreign goods, where $j \in[0,1]$ indicates the goods varieties and $\lambda>1$ is the elasticity of substitution among goods produced within a country.

Households own all home production and the importing firms and thus are recipients of profits, $\Pi_{t}$. Other sources of income for the representative household are wages $W_{t}$, and new borrowing net of interest payments on outstanding debts, both in domestic and foreign currency. Households have access to two types of non-contingent one-period debt; one denominated in domestic currency, $B_{t}$, and the other in foreign currency, $D_{t}^{H}$, with a nominal interest rate of $i_{t}$ and $i_{t}^{*} \Psi_{D, t}$. Due to imperfect capital mobility, households need to pay a premium, $\Psi_{D, t}$, given by $\Psi_{D, t}=\frac{\Psi_{D}}{2}\left[\exp \left(\frac{S_{t} D_{t+1}^{H}}{P_{t} G D P_{t}}-\frac{S D^{H}}{P G D P}\right)-1\right]^{2}$ when borrowing from the rest of the world. ${ }^{3}$

The representative household's budget constraint in period $t$ can, therefore, be written as follows:

$$
P_{t} C_{t}+\left(1+i_{t-1}\right) B_{t}+\left(1+i_{t-1}^{*}\right) \Psi_{D, t-1} S_{t} D_{t}^{H}=W_{t} H_{t}+B_{t+1}+S_{t} D_{t+1}^{H}+\Pi_{t}
$$

The representative household chooses the paths for $\left\{C_{t}, H_{t}, B_{t+1}, D_{t+1}^{H}\right\}_{t=0}^{\infty}$ in order to maximize its expected lifetime utility in (1) subject to the budget constraint in (3). ${ }^{4}$

\footnotetext{
${ }^{3}$ We introduce this premium for households' foreign borrowing to maintain the stationarity in the economy's net foreign assets. In our calibration, the elasticity of the premium with respect to the debt is very close to zero $\left(\Psi_{D, t}=0.0075\right)$ so that the dynamics of the model are not affected by the premium. See Schmitt- Grohe and Uribe (2003) for detailed discussions on other methods that induce stationarity in small open-economy models. Note that it would not be necessary to introduce this premium when solving the model with a global solution, which is not the case in this paper.

${ }^{4}$ When entrepreneurs are allowed to borrow from domestic sources, these funds are provided by households and channeled through financial intermediaries. In this case, the budget constraint is modified as follows:
} 


\section{$2.2 \quad$ Firms}

There are three types of firms in the model. Production firms produce a differentiated final consumption good using both capital and labor as inputs. These firms engage in local currency pricing and face price adjustment costs. As a result, final goods' prices are sticky in terms of the local currency of the markets in which they are sold. Importing firms that sell the goods produced in the foreign economy also have some market power and face adjustment costs in changing prices. Price stickiness in export and import prices causes the law of one price to fail such that exchange rate pass through is incomplete in the short run. Finally, there are competitive firms that combine investment with rented capital to produce unfinished capital goods that are then sold to entrepreneurs.

\subsubsection{Production firms}

Each production firm combines labour and capital to produce a differentiated good indexed by $j \in[0,1]$ using the production function:

$$
Y_{t}(j)=A_{t} N_{t}(j)^{1-\eta} K_{t}(j)^{\eta}
$$

where $A_{t}$ denotes labor productivity, common to all the production firms and $N_{t}(j)$ is the labor input which is a composite of household, $H_{t}(j)$, and entrepreneurial labor, $H_{t}^{E}(j)$; defined as $N_{t}(j)=H_{t}(j)^{1-\Omega} H_{t}^{E}(j)^{\Omega} . K_{t}(j)$ denotes capital provided by the entrepreneur, as is explored in the following subsection. Given that the price of each input is taken as given, the production firms minimize their costs subject to (4).

As mentioned above, firms have some market power and they segment domestic and foreign markets with local currency pricing, where $P_{H, t}(j)$ and $P_{X, t}(j)$ denote price in domestic market (in domestic currency) and price in foreign market (in foreign currency). Firms also face quadratic menu costs in changing prices expressed in the units of consumption basket given by $\frac{\Psi_{i}}{2}\left(\frac{P_{i, t}(j)}{P_{i, t-1}(j)}-1\right)^{2}$ for different market destinations $i=H, X .^{5}$

The individual firm maximizes its expected value of future profits using the household's intertemporal rate of substitution in consumption, given by $\beta^{t} U_{c, t}$, given that firms are owned by domestic households. Domestic and foreign demand for the domestically produced good $j$ are given by $Y_{H, t}(j)$ and $Y_{X, t}(j)$. We assume that different varieties have the same elasticities

$$
P_{t} C_{t}+D_{t+1}^{D}+\left(1+i_{t-1}^{*}\right) \Psi_{D, t-1} S_{t} D_{t}^{H}=W_{t} H_{t}+\left(1+i_{t-1}\right) D_{t}^{D}+S_{t} D_{t+1}^{H}+\Pi_{t} .
$$

where $D_{t+1}^{D}$ is domestic lending to entrepreneurs.

${ }^{5}$ The existence of menu costs generates a gradual adjustment in the prices of goods in both markets, as suggested by Rotemberg (1982). 
in both markets, so that the demand for good $j$ can be written as,

$$
Y_{i, t}(j)=\left(\frac{P_{i, t}(j)}{P_{i, t}}\right)^{-\lambda} Y_{i, t}, \text { for } i=H, X,
$$

where $P_{H, t}$ is the aggregate price index for goods sold in domestic market, as is defined earlier and $P_{X, t}$ is the export price index given by $P_{X, t} \equiv\left[\int_{0}^{1} P_{X, t}(j)^{1-\lambda} d j\right]^{1 /(1-\lambda)}$.

$Y_{X, t}$ denotes the foreign aggregate export demand for domestic goods and determined in the ROW block of the model.

The real exchange rate $R E X_{t}$ is defined as $R E X_{t}=\frac{S_{t} P_{t}^{*}}{P_{t}}$, where $S_{t}$ is the nominal exchange rate, domestic currency price of foreign currency, and $P_{t}^{*} \equiv\left[\int_{0}^{1} P_{t}^{*}(j)^{1-\lambda} d j\right]^{1 /(1-\lambda)}$ is the aggregate price index for foreign country's consumption goods in foreign currency.

\subsubsection{Importing firms}

The second set of firms are those of monopolistically competitive importing firms, which are owned by domestic households. These importing firms buy foreign goods at prices $S_{t} P_{t}^{*}$ and then sell to the domestic market. There is also a price adjustment cost facing the importing firms with $\Psi_{M} \succeq 0$, the cost of price adjustment parameter, analogous to the production firms. It, therefore, follows that there is some delay between exchange rates changes and the import price adjustments.

\subsubsection{Unfinished capital producing firms}

Aggregate investment in period $t$, denoted by $I_{t}$, is composed of domestic and final goods:

$$
I_{t}=\left[\alpha^{\frac{1}{\gamma}} I_{H, t}^{(\gamma-1) / \gamma}+(1-\alpha)^{\frac{1}{\gamma}} I_{M, t}^{(\gamma-1) / \gamma}\right]^{\gamma /(\gamma-1)}
$$

where the domestic and imported investment goods' prices are assumed to be the same as the domestic and imported consumer goods prices, $P_{H, t}$ and $P_{M, t}$. The new capital stock requires the same combination of domestic and foreign goods so that the nominal price of a unit of investment equals the price level, $P_{t}$. This implies that $I_{H, t}=\alpha\left(\frac{P_{H, t}}{P_{t}}\right)^{-\gamma} I_{t}$ and $I_{M, t}=(1-\alpha)\left(\frac{P_{M, t}}{P_{t}}\right)^{-\gamma} I_{t}$.

Competitive firms use investment as an input, $I_{t}$ and combine it with rented capital $K_{t}$ to produce unfinished capital goods. Allowing for adjustment costs, $\frac{\Psi_{I}}{2}\left(\frac{I_{t}}{K_{t}}-\delta\right)^{2}$ where $\delta$ is the depreciation rate, one can write the law of motion for capital as:

$$
K_{t+1}=\left[\frac{I_{t}}{K_{t}}-\frac{\Psi_{I}}{2}\left(\frac{I_{t}}{K_{t}}-\delta\right)^{2}\right] K_{t}+(1-\delta) K_{t}
$$


The optimality condition for the unfinished capital producing firms with respect to the choice of $I_{t}$ gives the nominal price of a unit of capital $Q_{t}$.

\subsection{Entrepreneurs}

As is the case in this class of models, entrepreneurs are key players. They transform unfinished capital goods that are then rent to the production firms. There is a continuum of entrepreneurs indexed by $k$ in the interval $[0,1]$. Each entrepreneur has access to a stochastic technology in transforming $K_{t+1}(k)$ units of unfinished capital into $\omega_{t+1}(k) K_{t+1}(k)$ units of finished capital goods. The idiosyncratic productivity $\omega_{t}(k)$ is assumed to be i.i.d. (across time and across firms), drawn from a distribution $F($.$) , with p.d.f of f($.$) and E()=.1 .^{6}$

Entrepreneurs finance their investment by external borrowing using the funds channeled through perfectly competitive financial intermediaries. The existing literature on financial crises in emerging market economies focuses exclusively on either foreign or domestic borrowing as a source of these funds. In this paper, we consider three alternative assumptions regarding the source of borrowing: (i) only foreign borrowing, (ii) only domestic borrowing and (iii) both foreign and domestic borrowing. It is well-known that the source of borrowing in an economy has important implications for the consequences of a financial crisis (see, for example, Gertler et al., 2007). This paper turns to exploring whether the composition of outstanding obligations may also affect how best to respond to financial market developments.

Next section explores the baseline case where entrepreneurs' borrowing from foreign lenders is set-out at length. We then describe how the model equations change under alternative borrowing assumptions.

\subsubsection{Only Foreign Borrowing}

As a benchmark scenario, we start off with the case where entrepreneurs can only borrow from foreign lenders and in foreign currency - a feature particularly relevant for emerging market countries. ${ }^{7}$ At the end of period $t$, each entrepreneur $k$ has net worth, $N W_{t}(k)$. The budget constraint of the entrepreneur can be expressed as follows:

$$
P_{t} N W_{t}(k)=Q_{t} K_{t+1}(k)-S_{t} D_{t+1}^{F}(k),
$$

\footnotetext{
${ }^{6}$ Following Bernanke et al. (1999) and Gertler et al. (2007), among others, the idiosyncratic productivity is assumed to be distributed $\log$-normally; $\log \left(\omega_{t}(k)\right) \sim N\left(\frac{-1}{2} \sigma_{\omega}^{2}, \sigma_{\omega}^{2}\right)$.

${ }^{7}$ See, Lane and Ferretti (2003) for international evidence on the scale of external borrowing.
} 
where $D_{t+1}^{F}$ denotes foreign currency denominated debt. Equation (8) simply states that capital financing is divided between net worth and foreign borrowing. It is clear that the entrepreneurs are exposed to exchange rate risk - fluctuations in the nominal exchange rate create balance sheet effects in the model.

Productivity is observed by the entrepreneur, but not by the lenders who have imperfect knowledge of the distribution of $\omega_{t+1}(k)$. Following Curdia (2007 and 2008) we specify the lenders perception of $\omega_{t+1}(k)$ as given by $\omega_{t+1}^{*}(k)=\omega_{t+1}(k) \varrho_{t}$ where $\varrho_{t}$ is the misperception factor over a given interval $[0,1]$. Further, the misperception factor, $\varrho_{t}$, is assumed to follow $\ln \left(\varrho_{t}\right)=\rho_{\varrho} \ln \left(\varrho_{t-1}\right)+\varepsilon_{\varrho}$ where $\rho_{\varrho}$ denotes the persistence parameter. We take the origin of the financial shock as a change in lenders' perception regarding idiosyncratic productivity $\left(\varepsilon_{\varrho}\right) \cdot{ }^{8}$

Entrepreneurs observe $\omega_{t+1}(k)$ ex post, but the lenders can only observe it at a monitoring cost which is assumed to be a certain fraction $(\mu)$ of the return. This corresponds to the costly state verification (CVS) problem indicated by Gale and Hellwig (1985). The contracting problem identifies the capital demand of entrepreneurs $K_{t+1}(k)$ and a cut off value, $\bar{\omega}_{t+1}(k)$, such that the entrepreneur maximizes their expected return subject to the participation constraints of the lender. ${ }^{9}$ The resulting first-order conditions are:

$$
E_{t}\left[R_{t+1}^{K}\right]=E_{t}\left[\left(1+i_{t}^{*}\right)\left(1+\Phi_{t+1}\right)\right]
$$

where $\left(1+\Phi_{t+1}\right)$ is the external risk premium.

A greater use of external financing generates an incentive for entrepreneurs to take on more risky projects, which raises the probability of default. This, in turn, will increase the external finance premium. Similarly, a fall in the entrepreneurs' net worth increases their leverage, leading to an upward adjustment in the external finance premium.

We follow the existing literature in assuming that a proportion of entrepreneurs die in each period to be replaced by new-comers. This assumption guarantees that self-financing never occurs and borrowing constraints on debt are always binding. As presented in Carl-

\footnotetext{
${ }^{8}$ We assume that when there is uncertainty about the underlying distribution, lenders take the worst case scenario as the mean of the distribution of $\omega_{t+1}(k)$. The details on the specification of the ambiguity aversion faced by lenders and the optimal contracting problem can be found in the Appendix to Ozkan and Unsal (2012).

${ }^{9}$ In the presence of aggregate uncertainty, the debt contracts with CVS that we focus on are known to be not optimal. In the contract, risk-averse (domestic and foreign) households are insured against aggregate uncertainty, as they receive non-state-contingent returns on their loans, channeled through financial intermediaries. This contract with perfect insurance, however, is not optimal because there could be a contract which provides a better insurance against aggregate uncertainty (by providing a state-contingent rate of return to households, but compensating them for this) and allows a debt contract with CVS to entrepreneurs. Note that the contract could be optimal for sufficiently risk-averse households as conjectured by Bernanke, Gertler, and Gilchrist (1999).
} 
strom and Fuerst (1997), the investment and monitoring technologies exhibiting constant returns to scale imply linearity and symmetry of the contracting problem such that all entrepreneurs face the same financial contract specified by the cut-off value and the external finance premium. This allows us to specify the rest of the model in aggregate terms.

\subsubsection{Only Domestic Borrowing}

As our second scenario, we explore the case of entrepreneurs' borrowing from only domestic lenders (households) and in domestic currency, opposite to the benchmark setting. One can think of this case as financial autarky where there is no access to international financial markets. Omitting entrepreneur index $k$ for notational simplicity, the budget constraint and the cost of borrowing facing the enterpreneur are given by:

$$
\begin{gathered}
P_{t} N W_{t}=Q_{t} K_{t+1}-D_{t+1}^{D}, \\
E_{t}\left[R_{t+1}^{K}\right]=E_{t}\left[\left(1+i_{t}\right)\left(1+\Phi_{t+1}^{D}\right)\right],
\end{gathered}
$$

where $D_{t+1}^{D}$ denotes domestic currency denominated debt and $\left(1+\Phi_{t+1}^{D}\right)$ denote default premia on domestic borrowing.

\subsubsection{Both Foreign and Domestic Borrowing}

Finally, we turn to a hybrid case where we allow both domestic and foreign borrowing. In this scenario, depending on the relative cost of borrowing from the two sources, entrepreneurs borrow both from domestic households (in domestic currency) and from foreign lenders (in foreign currency). ${ }^{10}$ We conceptualize these two different types of borrowing as representing two different types of entrepreneurs ( $F$ and $D$ for borrowing in foreign and domestic currency terms, respectively) at the aggregate level. The budget constraints of the entrepreneurs now take the following form:

$$
\begin{gathered}
P_{t} N W_{t}^{F}(k)=Q_{t} K_{t+1}^{F}(k)-S_{t} D_{t+1}^{F}(k), \\
P_{t} N W_{t}^{D}(k)=Q_{t} K_{t+1}^{D}(k)-D_{t+1}^{D}(k) .
\end{gathered}
$$

\footnotetext{
${ }^{10}$ Note that in the absence of cost differences, entrepreneurs would be indifferent between borrowing from domestic and foreign lenders, and therefore the amount domestic and foreign borrowing would be equal in the steady state.
} 
where superscript $v$ is used for the type of borrowing, $v=F, D$.

We maintain that each entrepreneur's technology function could be written as $\omega_{t+1}^{v}(k) K_{t+1}^{v}(k)$. Given that there are no informational frictions between foreign and domestic lenders in our model, foreign and domestic lenders' perception is assumed to share the same dynamics; $\omega_{t+1}^{v *}(k)=\omega_{t+1}^{v}(k) \varrho_{t}$.

The resulting first order conditions yield:

$$
\begin{aligned}
& E_{t}\left[R_{t+1}^{K}\right]=E_{t}\left[\left(1+i_{t}^{*}\right)\left(1+\Phi_{t+1}^{F}\right)\right], \\
& E_{t}\left[R_{t+1}^{K}\right]=E_{t}\left[\left(1+i_{t}\right)\left(1+\Phi_{t+1}^{D}\right)\right] .
\end{aligned}
$$

The total capital in the economy with two types of enterpreneurs is the sum of capital provided by each; $K_{t}=K_{t}^{F}+K_{t}^{D}$.

\subsection{Financial intermediaries and macroprudential policy}

There exists a continuum of perfectly competitive financial intermediaries who channel funds from lenders to entrepreneurs. In the baseline case with only foreign borrowing, the zero profit condition implies that the lending rates are equal to $E_{t}\left[\left(1+i_{t}^{*}\right)\left(1+\Phi_{t+1}^{F}\right)\right]$ in the absence of macroprudential measures.

How does macroprudential policy influence the lending rate? The policy debate has already established a list of instruments that could be used to preserve the stability of the financial system. These included countercyclical capital requirements, time-varying margins on certain financial transactions, limits on interbank exposure, size dependent leverage limits and caps on loan-to-value ratios, among others (see, for example, Bank of England, 2009 and IMF, 2011). It is widely understood that, irrespective of its specific form, macroprudential policy would create higher costs for financial intermediaries (see, Angelini et al., 2010).

We therefore base our formulation of macroprudential policy on this notion rather than deriving the impact of a particular type of macroprudential measure on the borrowing cost. We follow Kannan et al. (2012), Unsal (2013), and Quint and Rabanal (2014) to focus on a generic case where macroprudential measures raise the cost of financial intermediation. These costs are then passed onto borrowers in the form of higher interest rates. ${ }^{11}$ We refer to the increase in lending rates brought by macroprudential measures as the "regulation premium" and maintain that it is linked - positively- to nominal credit growth. Macroprudential policy

\footnotetext{
${ }^{11}$ By adopting a more eloborate banking sector, Angelini et al. (2010) show that macroprudential measures indeed lead to a rise in the cost of borrowing. In our an open economy framework, following a similar approach would make the model intractable. Therefore, we use a simpler specification here, and leave the analysis of frictions facing financial intermediaries for future work.
} 
is therefore countercyclical by design: countervailing to the natural decline in perceived risk in good times and the subsequent rise in the perceived risk in bad times.

In the presence of macroprudential regulations, the spread between the lending rate and the policy rate is affected by both the external finance and the regulation premium. Hence, the lending cost for foreign borrowing, $E_{t}\left[R_{t+1}^{K}\right]$ becomes:

$$
E_{t}\left[R_{t+1}^{K}\right]=E_{t}\left[\left(1+i_{t}^{*}\right)\left(1+\Phi_{t+1}\right)\left(1+R P_{t}\right)\right]
$$

where $R P_{t}$ is the regulation premium, which is defined as a function of the credit growth in the economy. In the baseline case, it is given by:

$$
R P_{t}=\Psi\left(\frac{S_{t} D_{t}^{F}}{S_{t-1} D_{t-1}^{F}}-1\right)
$$

In this definition of macroprudential policy, it is implicit that the policy objective is defined in terms of aggregate credit activity. Reasons for the choice of credit growth as our preferred financial market indicator are two-fold. First, restrictions on credit or credit growth have been among the most widely used macroprudential measures since $2008 .{ }^{12}$ Second, the structure of our basic model with explicit financial frictions provides a natural setting to explore the impact of policy responses to the changes in credit growth in a tractable manner.

\subsection{Monetary policy}

As in Schmitt-Grohe and Uribe (2007) and Faia and Monacelli (2007), we model monetary policy in terms of simple implementable rules in which the central bank sets the policy rate in response to some observable variables:

$$
1+i_{t}=\left[(1+i)\left(\pi_{t}\right)^{\epsilon_{\pi}}\left(Y_{t} / Y\right)^{\epsilon_{Y}}(\text { credit growth })^{\epsilon_{D}}\right]^{\varpi}\left[1+i_{t-1}\right]^{1-\varpi}
$$

with $\left\{\epsilon_{\pi}\right\} \in(1, \infty],\left\{\epsilon_{Y}\right\} \in(0, \infty],\left\{\epsilon_{D}\right\} \in(-\infty, \infty]$, and $\varpi \in[0,1]$. In (18) $\varpi$ is the interest rate smoothing parameter, $i$ and $Y$ denote the steady-state levels of nominal interest rate and output, $\pi_{t}$ is the CPI inflation and (credit growth) denotes nominal credit growth in the economy in domestic currency terms. We start with an initial set of values for $\epsilon_{\pi}, \epsilon_{Y}, \epsilon_{D}$, and $\varpi$ in the calibration. We then derive $\left\{\epsilon_{\pi}, \epsilon_{Y}, \epsilon_{D}\right\}$ as well as $\Psi$ (the coefficient of nominal credit growth in the macroprudential tool) optimally by computing the values that maximize the total welfare of economic agents (further discussion is presented below).

\footnotetext{
${ }^{12}$ See, for example, Lim et al. (2011).
} 


\section{Model parametrization}

We calibrate the model for a generic emerging market economy, using established values in the literature. Table 1 summarizes the parametrization of the model for consumption, production, entrepreneurial sector and monetary policy. The discount factor, $\beta$ is set at 0.99 , implying a riskless annual return of approximately 4 per cent in the steady state (time is measured in quarters). We set the inverse of the elasticity of intertemporal substitution, $\sigma$ at 1 , in line with much of the literature. The inverse of the elasticity of labour supply $\varphi$ is set at 2 . The degree of openness, $(1-\alpha)$, and the share of capital in production, $\eta$, are set at 0.35, consistent with Gertler et al. (2007). Following Devereux et al. (2006), the elasticity of substitution between differentiated goods of the same origin, $\lambda$, is taken to be 11, implying a flexible price equilibrium mark-up of 1.1, and price adjustment cost is assumed to be 120 for all sectors. The quarterly depreciation rate $\delta$ is taken to be 0.025 , a conventional value used in the literature. The share of entrepreneurs' labour, $\Omega$, is set at 0.01 , implying that 1 per cent of the total wage bill goes to the entrepreneurs. With respect to monetary policy, we use the original Taylor estimates and set $\epsilon_{\pi}=1.5$ and $\epsilon_{Y}=0.5$ in the baseline calibration. The degree of interest rate smoothing parameter $(\varpi)$ is chosen as 0.5 . Similarly, $\rho_{\varrho}$ is taken to be 0.5 , so that it takes 9 quarters for the shock to die away. The steady state leverage ratio and the value of quarterly external risk premium in the domestic economy are set at 0.3 and 200 basis points. We set the monitoring cost parameter, $\mu$, at 0.2 as in Devereux et al. (2006). These parameter values imply a survival rate, $\vartheta$, of approximately 99.33 per cent.

\section{Model dynamics}

\subsection{Monetary and macroprudential policy}

In this section, we explore the interaction between the financial sector and the real economy and the role of monetary and macroprudential policies in mitigating the impact of financial and productivity shocks.

We first consider an unanticipated financial shock - leading to one per cent rise in the perceived risk- which results in a reversal of capital of about 2.5 percent of output under the baseline scenario. We characterize this scenario as an unfavorable perception shock regarding the credit worthiness of the domestic borrowers, reflecting the commonly observed phenomenon of widespread pessimism in financial markets during financial crisis episodes. When the investors' perception about the distribution of the entrepreneurs' productivity changes, lending to domestic entrepreneurs becomes more risky, leading to a rise in the external finance 
premium on impact. As the cost of borrowing rises, entrepreneurs reduce their use of external financing by undertaking fewer projects. This decline in leverage causes a downward adjustment in the risk premium, mitigating the initial impact of the financial shock. Lower borrowing, however, decreases the future supply of capital and hence brings about a decrease in investment in the economy. The fall in the inflow of capital also lowers the demand for domestic currency, leading to its depreciation. Since the entrepreneurs' borrowing is denominated in foreign currency, this unanticipated change in the exchange rate also creates balance sheet effects through a rise in the real debt burden.

We then turn to the case of a negative productivity shock of 1 percent in magnitude, leading to a fall in consumption, investment and output but a rise in inflation. A key difference between the financial and the productivity shock is that there is a tension between macroeconomic and financial stability objectives as inflation and credit growth move in opposite directions in the latter as opposed to in the former. An unfavorable productivity shock brings about a fall in real variables such as consumption, investment and output as well as in credit growth, asset prices and capital flows, similar to the case of financial shock. However, in contrast to falling inflation under the financial shock, inflation rises following the productivity shock leading to a rise in policy rate and the following fall in real exchange rate. The fact that credit growth and inflation move in opposite directions presents a trade-off between macroeconomic and financial stability objectives, with implications for the welfare ranking of alternative policy regimes.

\subsection{Should monetary policy lean against the wind?}

Figures 1-4 present the impact of the two shocks under three different policy options: (i) standard Taylor rule; (ii) a macroprudential instrument accompanying the Taylor rule; and (iii) Taylor rule that responds to the nominal credit growth.

In the first scenario with the financial shock (Figure 1-2), policy rates are lowered in response to a negative output gap and lower inflation (see Table 2 for the coefficients of macroeconomic variables in all three scenarios). The lower policy rate partially offsets the impact of the higher risk premium on lending rates, and stabilizing output as consumption becomes less costly. The stabilization of demand also helps to raise inflation.

Figure 1 compares impulse responses under the standard Taylor rule (18) with Taylor rule combined with a macroprudential instrument that directly counteracts the tightening of lending conditions and thus the financial accelerator effect. As is seen from Figure 1, macroprudential policy dampens the responses of all (plotted) real and financial variables. The reason for this is that given the counter-cyclical nature of macroprudential policy, reg- 
ulation premium falls following the unfavorable financial shock, reducing the lending rate, which helps contain the fluctuations in the economy. Therefore, the consequences for output and inflation are also more muted.

In Figure 2, we present a case where policymakers react to nominal credit growth in the Taylor rule, above and beyond its effect on output gap and inflation. As a result, the policy rate is lowered more under this regime, relative to the first scenario, which helps mitigate the impact of the shock on lending rates. Indeed, the decreases in consumption, investment and output, as well as in asset prices and credit growth are all lower under this regime. Lower interest rates lead to the exchange rate to depreciate further. This, together with a lower decline in investment and consumption, leads to a smaller fall in inflation, as compared with the one under the standard Taylor rule. As a result, responses of output and inflation are more muted in spite of policy also responding to credit growth under this regime.

So far, the responses to macroeconomic and financial variables through monetary policy and macroprudential measures are aligned - both are expansionary. How do the responses change with a reaction to financial market developments when there is a trade-off between macroeconomic and financial stability objectives? The responses of the economy to a productivity shock under the three policy regimes are presented in Figures 3 and 4 . The falls in investment, output, credit growth and asset prices are smaller in the presence of macroprudential policy (Figure 3). However, expansionary macroprudential policy under that scenario results in higher inflation, by undoing some of the tightening brought about by the rise in the policy rate. Figure 4 illustrates that when there is a response to credit growth in the Taylor rule, the impact of the productivity shock on output and credit are mitigated when compared with the standard Taylor rule. Similar to the case with macroprudential policy, however, inflation rises by about 50 percent more compared to the baseline case. It therefore appears that under the productivity shock, responding to financial market developments improves financial stability, but not necessarily macroeconomic stability.

Overall, our results suggest that leaning against the wind in the face of the financial shock through either the policy rate or the macroprudential instrument helps improve macroeconomic and financial stability. However, stabilization benefits of responding to financial market developments decline under a productivity shock.

As stated above, our analysis in this section is based on exogenously given parameters in both the monetary and the macroprudential rule. Next section re-examines the question of how best to respond to financial instability when policy rules are set in an optimal way. 


\section{$5 \quad$ Optimal policy rules and welfare evaluations}

We consider the welfare gains from responses to financial market developments - proxied by nominal credit growth in our experiments- through monetary and macroprudential policy instruments, and compute the optimal degree of reaction/intervention. We take the utility function of consumers as the objective.

Following Faia and Monacelli (2007), and Gertler and Karadi (2010), we start with expressing the household utility function recursively:

$$
V_{t}=U\left(C_{t}, H_{t}\right)+\beta E_{t} V_{t+1}^{H H}
$$

where $V_{t} \equiv E_{0} \sum_{t=0}^{\infty} \beta^{t} U\left(C_{t}, H_{t}\right)$ denotes the utility function of households. We then take a second order approximation of $V_{t}$ around deterministic steady state. Using the second order solution of the model, we then calculate $V_{t}$ in each of the separate cases of monetary and macroprudential policies. We present a comparative analysis of alternative policies in terms of a consumption equivalent, $\Upsilon$, given by the fraction of consumption required to equate welfare under any given monetary and macroprudential policies, $V_{t}^{*}$, to the one under the optimal Taylor rule, $V_{t}^{\text {opt }}$. In our specification of the utility function, and under $\sigma=2$,

$$
\Upsilon=\left(\frac{\left(V_{t}^{o p t}-V_{t}\right)(1-\beta)\left(C-\frac{\chi}{1+\varphi} H^{1+\varphi}\right)^{2}}{C\left(1-\left(V_{t}^{\text {opt }}-V_{t}\right)(1-\beta)\left(C-\frac{\chi}{1+\varphi} H^{1+\varphi}\right)\right)}\right.
$$

where the variables without subscripts are the steady state values of the corresponding variables. As presented in Table 3 and Table $5, \Upsilon$ is a measure of welfare loss in units of steady state consumption - a higher $\Upsilon$ implies a higher welfare loss, and hence indicates that the policy is less desirable from a welfare point of view. To find the optimal simple monetary and macroprudential policy rules, we then search numerically in the grid of parameters $\left\{\epsilon_{\pi}, \epsilon_{y}, \epsilon_{D}, \Psi\right\}$ that optimize $V_{t}$ in response to the financial and productivity shocks. Table 4 and Table 6 show the optimized monetary and macroprudential policy parameters.

\subsection{Optimal monetary versus macroprudential policy rules}

Under both financial and the productivity shocks, we find that the optimal response to inflation is close to unity, and response to output gap is zero in line with Schmitt-Grohe and Uribe (2007) and Faia and Monacelli (2007). Hence, in what follows we set $\epsilon_{Y}$ to zero, and focus on the parameters of inflation and nominal credit growth in the monetary policy rule, 
and nominal credit growth in the macroprudential policy rule. ${ }^{13}$

Clearly, responding to credit market developments following a financial shock is welfare improving. The welfare loss decreases by about 0.05 and 0.1 percent of steady state consumption under Taylor rule with a credit growth response and macroprudential policy rule, respectively (Table 3). More interestingly, even when the coefficients of the Taylor rule are optimized to minimize the welfare losses in response to the shock, the optimized coefficient for credit growth in the macroprudential instrument is not zero (1.1) (Table 4). The presence of the macroprudential instrument, however, calls for a more aggressive monetary policy response to inflation (2.4 as opposed to 1.1). This is because a strong expansionary macroprudential response could outweigh the negative impact of the shock on credit conditions, and result in increases in demand and inflation, which calls for a more aggressive anti-inflationary stance. Nonetheless, the improvement in welfare from using the macroprudential instrument is significant (0.1 percent of steady state consumption) compared to even the optimal Taylor rule. The optimized coefficient for the credit growth in the Taylor rule is not zero either (0.6), but the welfare gains relative to the optimal Taylor rule are rather small (0.03).

In the face of a financial shock, there is little role for financial market developments in the monetary policy rule when the macroprudential instrument is in place. As shown in Table 3, the welfare effects of incorporating nominal credit growth in the policy rule (last row) is negligible. Consistently, the optimized coefficient is also close to zero (Table 4).

Table 5 and Table 6 present the welfare losses and the optimized coefficients of alternative policies following the productivity shock. The welfare loss increases by about 0.12 percent of steady state consumption when the policy rate responds to credit growth. Not surprisingly, the coefficient of the nominal credit growth in Taylor rule turns out to be zero (Table 6). Under a productivity shock, macroprudential measures also decrease welfare, but welfare costs are $1 / 5$ of the costs under the policy where Taylor rule responds to credit growth.

Our experiment shows that optimized response to financial market developments in monetary and macroprudential rules vary depending on the source of the shock - unlike the case of a financial shock, a response to financial market developments is not desirable in the case of a productivity shock. However, in real-time, policymakers generally need to act without observing the true nature of the shock. Therefore, systematic responses to financial market developments through monetary or macroprudential tools need to be "robust" or to minimize costs of policy mistakes if they happen. In our framework, delegating the "lean against the wind" to macroprudential policy is either welfare improving (under a financial shock) or less

\footnotetext{
${ }^{13}$ We only report the results for interest rate inertia coefficient $\varpi=0.5$. The optimized coefficients and welfare evaluations slightly change for varying values of $\varpi$, but the results remain valid.
} 
costly (under a productivity shock), and hence provide a policy combination that is more robust to shock uncertainty.

\subsection{The role of the borrowing source}

The source of borrowing (foreign versus domestic) plays an important role in the desirability of alternative policies in responding the financial market developments. There are two reasons for this. First, with foreign borrowing (denominated in foreign currency), the depreciation of the exchange rate reduces entrepreneurial net worth and amplifies the financial accelerator mechanism, thereby leading to a more severe impact on the financial sector. As a result, promoting financial stability through monetary policy would require a more aggressive response, jeopardizing macroeconomic stability. Second, when the only source of credit for entrepreneurs is external, the borrowing cost is a function of the foreign interest rate, external finance premium, and the regulation premium (16). Hence, in contrast to the macroprudential policy, the policy rate does not directly influence the cost of credit, and consequently responding to financial market developments through the monetary policy instrument is less effective. In contrast, when borrowing is of domestic origin only, the policy rate directly influences the cost of credit. In this case, the benefits of using two separate instruments relative to responding financial markets through policy rate tend to be negligible. ${ }^{14}$

We now turn to welfare results and optimized coefficients under the three different borrowing assumptions, as presented in Table 7. Welfare outcomes reveal that, under foreign borrowing, responding to financial market developments using the monetary instrument following a financial shock is much inferior - about 7 percent of steady state consumption- than using the macroprudential instrument. Indeed, the optimized coefficient for credit growth in the macroprudential rule (1.14) is higher than the optimized coefficient of credit growth in the monetary policy rule (0.63). The difference in welfare gains (optimized coefficients) between using the two policies narrows down to about 2 percent (0.3) when the model allows for both foreign and domestic borrowing. When borrowing is only of domestic type, responding through the policy rate or the macroprudential instrument becomes indifferentiable from a welfare point of view, and the optimized coefficients for the nominal credit growth in both instrument are very close. Note that the welfare gains from both policies are smaller under domestic borrowing as compared with the other two cases, as the impact of the shock on the financial sector and the overall economy is smaller in this case, as mentioned previously.

\footnotetext{
${ }^{14}$ As discussed before, macroprudential policy could still target specifically the financial sector as opposed to the Taylor type broad policy instrument (which also affects consumption) and therefore is expected to be welfare-superior.
} 
The finding that the source of borrowing matters for the choice of policy instrument in responding to credit market developments has practical policy implications. For emerging market economies where the size of foreign borrowing is typically large, using monetary policy in promoting financial stability is likely to generate more macro-financial instability than using macroprudential measures. Indeed, countries with significant external obligation have employed a number of macroprudential tools after the global financial crisis (IMF, 2012).

\section{Conclusions}

A key lesson from the recent financial crisis experience is that the objective of financial stability should be made a central part of macroeconomic management. Motivated by this issue, we explore how best to design monetary and macroprudential policies in an open economy New Keynesian general equilibrium model, incorporating the complementarities between the two sets of policies.

In our set-up, a response to credit market developments through monetary policy entails a reaction to a financial market variable in the policy rule while macroprudential policy imposes costs on financial intermediaries that are then passed onto borrowers. We have modelled the initial shock as an increase in investors' perception of risk, which leads to a sudden reversal of capital inflows and hence tightening in credit conditions. Given the explicit consideration of financial frictions, both monetary and macroprudential policies have a non-trivial role in mitigating the impact of this shock.

Our results can be summarized as follows. First, following a financial shock, leaning against the wind either through the policy rate or through macroprudential measures help towards macroeconomic and financial stability, although macroprudential policy does a better job quantitatively. However, when macroprudential measures are in place, welfare gains from responding to credit growth through traditional monetary policy tools is negligible. Moreover, under a productivity shock, it is more costly from welfare point of view to respond to financial market developments through monetary policy than through macroprudential policies. Therefore, using monetary and macroprudential policies to the pursuit of two separate objectives - monetary and financial stability - would provide a policy mix that is more robust to shock uncertainty. Second, we find that in economies with sizable foreign borrowing, using a separate macroprudential instrument is even more desirable. The reason for this is that, as opposed to the macroprudential tool, monetary policy cannot directly influence the cost of foreign borrowing, and hence promoting financial stability would require large policy rate changes which exacerbate macroeconomic and financial volatility. 
In this paper, among other simplifying assumptions, we maintained that exchange rate is fully flexible. We have thus excluded exchange rate interventions from the policy toolkit which includes monetary and macroprudential policy rules. However, many emerging markets have intervened in foreign exchange markets during and after the global financial crisis to dampen movements in exchange rates and smooth the impact of volatile capital flows. We believe that examination of this issue together with monetary and macroprudential policies can make important contributions to our understanding of how best to preserve the stability of financial systems following a shock to capital inflows and intend to take up these issues in future research. 


\section{References}

[1] Angelini, I., E. Faia and D. Marco Lo (2010). Monetary policy and risk taking. Bruegel Working Paper.

[2] Angeloni, P. and E. Faia (2009). A tale of two policies: Prudential regulation and monetary policy with fragile banks. Kiel Working Paper 1569.

[3] Bank for International Settlements (2010). Group of Central Bank Governors and Heads of Supervision reinforces Basel Committee reform package. BIS press release, 11 January 2010.

[4] Benigno, G., C. Huigang, O. Christopher, R. Alessandro and E. Young (2013). Financial crisis and macroprudential policies. Journal of International Economics, 89 (2), 453470 .

[5] Bernanke, B. S., M. Gertler, and S. Gilchrist (1999). The financial accelerator in a quantitative business cycle framework. In J. B. Taylor and M. Woodford (Eds.), Handbook of Macroeconomics, Volume 1C, Chapter 21, pp. 1341-93. Amsterdam: North-Holland.

[6] Bianchi, J. (2011). Overborrowing and systemic externalities in the business cycle. American Economic Review, 101(7), December, 3400-3426.

[7] Bianchi, J. , and E. G. Mendoza (2011). Overborrowing, financial crises and 'macroprudential' policy? IMF Working Paper 11/24.

[8] Borio C.E.V. and P.W. Lowe (2002). Asset prices, financial and monetary stability: exploring the nexus. BIS Working Paper, No. 114.

[9] Cecchetti, S. G. (2008). Measuring the macroeconomic risks posed by asset price booms. In J. Y. Cambell (Ed.), Asset prices and monetary policy ( 9-34). Chicago: University of Chicago Press.

[10] Curdia, V. (2007). Monetary policy under sudden stops. Staff Report No. 278. Federal Reserve Bank of New York.

[11] Curdia, V. (2008). Optimal monetary policy under sudden stops. Staff Report no. 323, Federal Reserve Bank of New York.

[12] De Paoli, B. (2009). Monetary policy and welfare in a small open economy. Journal of International Economics, 77(1), 11-22.

[13] Devereux, M. B., P. R. Lane, and J. Xu (2006). Exchange rates and monetary policy in emerging market economies. The Economic Journal, 116, 478-506. 
[14] Faia, E. and T. Monacelli (2007). Optimal interest rate rules,asset prices and credit frictions. Journal of Economic Dynamics \& Control, 31, 3228-3254.

[15] Galí, J. and T. Monacelli (2005). Monetary policy and exchange rate volatility in a small open economy. Review of Economic Studies, 72 (3), 707-734.

[16] Gertler, M. and P. Karadi (2010). A model of unconventional monetary policy. Journal of Monetary Economics, 58, 17-34.

[17] Gertler, M., S. Gilchrist, and F. Natalucci (2007). External constraints on monetary policy and the financial accelerator. Journal of Money, Credit and Banking, 39, $295-330$.

[18] Greenwood, J., Z. Hercowitz, and G. Huffman (1988). Investment, capacity utilization and the real business cycles. American Economic Review, 78 402-417.

[19] International Monetary Fund (2011). World Economic Outlook: Tensions from the TwoSpeed Recovery: Unemployment, Commodities, and Capital Flows. Washington, April.

[20] International Monetary Fund (2012). Interaction of monetary and macroprudential policies: Background Paper. Washington, April.

[21] Jeanne, O. and A. Korinek (2010). Managing credit booms and busts: a pigouvian taxation perspective. NBER Working Paper 16377.

[22] Kannan, P. , P. Rabanal, and A. Scott (2012). Monetary and macroprudential policy rules in a model with house price booms, B.E. Journal of Macroeconomics, Contributions, Vol. 12, Issue 1, Article 16.

[23] Korinek, A. (2009). Systemic risk-taking: accelerator effects, externalities, and regulatory responses. Mimeo, University of Maryland.

[24] Lane, P. and G. Milesi-Ferretti (2003). International financial integration. IMF Staff Papers, 50, 82-113.

[25] Lim, C., F. Columba, A. Costa, P. Kongsamut, A. Otani, M. Saiyid, T. Wezel, and X. Wu (2011). Macroprudential policy: what instruments and how to use them? IMF Working Paper, No.11/238.

[26] Medina, J.P., and J. Roldos (2014). Monetary and macroprudential policies to manage capital flows. IMf Working Paper, 14/30. Washington DC.

[27] Mishkin, F. S. (2011) How should central banks respond to asset-price bubbles? The ' lean versus clean' debate after the GFC. Bulletin, Reserve Bank of Australia, June 2011. 
[28] Ozkan, G. and D. F. Unsal (2012). Global financial crisis, financial contagion, and emerging markets. IMF Working Paper, No. 12/293. Washington DC.

[29] Quint, D., and P. Rabanal (2014). Monetary and macroprudential policy in an estimated DSGE model of the Euro Area." International Journal of Central Banking, forthcoming.

[30] Reinhart, C. and K. Rogoff. (2009). This Time is Different. Eight Centuries of Financial Folly. The Princeton University Press.

[31] Rotemberg, J. (1982). Sticky prices in the United States. Journal of Political Economy, $90,1187-1211$.

[32] Schmitt-Grohe, S. and M. Uribe (2003). Closing small open economy models. Journal of International Economics, 61, 163-185.

[33] Schmitt-Grohe, S. and M. Uribe (2007). Optimal simple and implementable monetary and fiscal rules. Journal of Monetary Economics. 54(6), 1702-1725.

[34] Taylor, J, 2008. The financial crisis and the policy responses: and empirical analysis of what went wrong. Keynote lecture at the Bank of Canada, Ottawa, November.

[35] Unsal, D. F. (2013). Capital flows and financial stability: monetary policy and macroprudential responses. International Journal of Central Banking, 9(1), 233-285. 
Table 1: Parameter Values for Consumption, and Production Sectors

\begin{tabular}{ll}
\hline \hline & \\
$\beta=0.99$ & Discount factor \\
$\sigma=2$ & Inverse of the intertemporal elasticity of substitution \\
$\gamma=1$ & Elasticity of substitution between domestic and foreign goods \\
$\varphi=2$ & Frisch elasticity of labour supply \\
$(1-\alpha)=0.35$ & Degree of openness \\
$\eta=0.35$ & Share of capital in production \\
$\lambda=11$ & Elasticity of substitution between domestic goods \\
$\delta=0.025$ & Quarterly rate of depreciation \\
$\Omega=0.01$ & Share of entrepreneurial labor \\
$\Psi_{I}=12$ & Investment adjustment cost \\
$\Psi_{D}=0.0075$ & Responsiveness of household risk premium to debt/GDP \\
$\Psi_{i}, \Psi_{M}=120$ & Price adjustment costs for $i=H, X$ \\
$\varpi=0.5$ & Inertia in the policy rule \\
$\rho_{\varrho}=0.5$ & Persistence of the domestic perception shock \\
$\Phi_{t}=0.02$ & External risk premium \\
$\mu=0.2$ & Monitoring cost \\
$\vartheta=0.9933$ & Survival rate \\
\hline \hline
\end{tabular}


Table 2: Parameters of the Policy Rules and the Macroprudential Instrument

\begin{tabular}{lllcc}
\hline \hline & \multicolumn{3}{c}{ Monetary policy } & Macroprudential policy \\
\cline { 2 - 5 } & Inflation & Output gap $\dot{+}$ & Credit gr. & Credit gr. \\
Taylor rule & 1.5 & 0.5 & 0 & 0 \\
Taylor rule with credit gr. & 1.5 & 0.5 & 0.75 & 0 \\
Taylor rule + macroprud. & 1.5 & 0.5 & 0 & 0.75 \\
\hline \hline
\end{tabular}

$\dot{+}$ Output gap is calculated as a deviation of output from its steady state.

Table 3: Welfare Results for Alternative Policies in Response to a Financial Shock

\begin{tabular}{lc}
\hline \hline & Welfare Loss $(\Upsilon)^{\curlywedge}$ \\
Taylor rule (TR) & 0.2106 \\
TR with credit growth (CG) & 0.1593 \\
TR + macroprud. policy (MP) & 0.1140 \\
Optimized Taylor rule (OTR) & - \\
OTR with CG & -0.0324 \\
OTR + optimized MP (OMP) & -0.1098 \\
OTR with CG+ OMP & -0.1178 \\
\hline \hline
\end{tabular}

$\curlywedge_{\text {Welfare loss }}(\Upsilon$ ) is expressed in units of steady state consumption. It represents the fraction of consumption (in \%) required to equate welfare under any given policy rule to the one under the optimal simple rule (see Equation (20)), in the face of a $1 \%$ financial shock. Welfare is calculated as conditional to the initial deterministic steady state in each case. 
Table 4: The Optimized Coefficients of Monetary and Macroprudential Policy Rules in Response to a Financial Shock*

\begin{tabular}{llclc}
\hline \hline & \multicolumn{3}{c}{ Monetary policy } & Macropru. policy \\
\cline { 2 - 5 } Opt.Taylor rule (OTR) & 1.1 & 0 & - & Credit gr. \\
OTR with CG & 1.1 & - & 0.6 & - \\
OTR + OMP & 2.4 & - & - & - \\
OTR with CG+OMP & 1.7 & - & 0.1 & 0.1 \\
\hline \hline
\end{tabular}

+Output gap is calculated as a deviation of output from its steady state.

*We calculate the optimized parameters by searching numerically in the grid of parameters $\left\{\epsilon_{\pi}, \epsilon_{y}, \epsilon_{D}, \Psi\right\}$ that optimize welfare $V_{t}$ in response to the $1 \%$ financial shock. Welfare is calculated as conditional to the initial deterministic steady state in each case.

Table 5: Welfare Results for Alternative Policies in Response to a Productivity Shock

\begin{tabular}{ll}
\hline \hline & Welfare Loss $(\Upsilon)^{\curlywedge}$ \\
Taylor rule (TR) & 0.2163 \\
TR with credit growth (CG) & 0.3302 \\
TR + macroprud. policy (MP) & 0.2411 \\
Optimized Taylor rule (OTR) & - \\
OTR with CG & - \\
OTR + optimized MP (OMP) & - \\
OTR with CG+ OMP & - \\
\hline \hline
\end{tabular}

$\curlywedge_{\text {Welfare loss }}(\Upsilon$ ) is expressed in units of steady state consumption. It represents the fraction of consumption (in \%) required to equate welfare under any given policy rule to the one under the optimal simple rule (see Equation (20)), in the face of a $1 \%$ productivity shock. Welfare is calculated as conditional to the initial deterministic steady state in each case. 
Table 6: The Optimized Coefficients of Monetary and Macroprudential Policy Rules in Response to a Productivity Shock*

\begin{tabular}{llllc}
\hline \hline & \multicolumn{3}{c}{ Monetary policy } & Macropru. policy \\
\cline { 2 - 5 } Opt.Taylor rule (OTR) & 1.1 & 0 & - & Credit gr. \\
OTR with CG & 1.1 & - & 0 & - \\
OTR + OMP & 1.1 & - & - & - \\
OTR with CG+OMP & 1.1 & - & 0 & 0 \\
\hline \hline
\end{tabular}

$\dot{+}$ Output gap is calculated as a deviation of output from its steady state.

${ }^{*}$ We calculate the optimized parameters by searching numerically in the grid of parameters $\left\{\epsilon_{\pi}, \epsilon_{y}, \epsilon_{D}, \Psi\right\}$ that optimize welfare $V_{t}$ in response to the $1 \%$ productivity shock. Welfare is calculated as conditional to the initial deterministic steady state in each case.

Table 7: The Optimized Responses to Credit Markets under a Financial Shock: Sources of Borrowing

\begin{tabular}{lllll}
\hline \hline Sources of Borrowing & \multicolumn{2}{l}{ Welfare Loss $(\Upsilon)^{\curlywedge}$} & \multicolumn{2}{c}{ Opt. Coefficent of Credit Gr.* } \\
\hline \multirow{3}{*}{ Foreign } & Opt. Taylor Rule & Opt. MP Rule & Taylor Rule & MP Rule \\
Domestic & -0.0321 & -0.1098 & 0.63 & 1.14 \\
Domestic and Foreign & -0.0205 & -0.0310 & 0.47 & 0.65 \\
\hline \hline
\end{tabular}

$\curlywedge_{\text {Welfare loss }}(\Upsilon$ ) is expressed in units of steady state consumption. It represents the fraction of consumption (in \%) required to equate welfare under any given policy rule to the one under the optimal simple rule (see Equation (20)), in the face of a $1 \%$ financial shock. Welfare is calculated as conditional to the initial deterministic steady state in each case.

${ }^{*}$ We calculate the optimized responses by searching numerically in the grid of parameters $\left\{\epsilon_{\pi}, \epsilon_{y}, \epsilon_{D}, \Psi_{\}}\right.$that optimize welfare $V_{t}$ in response to the $1 \%$ financial shock. Welfare is calculated as conditional to the initial deterministic steady state in each case. 
Figure 1. A Negative Financial Shock: Taylor Rule and Macroprudential Policy† (percent deviations from the steady state)
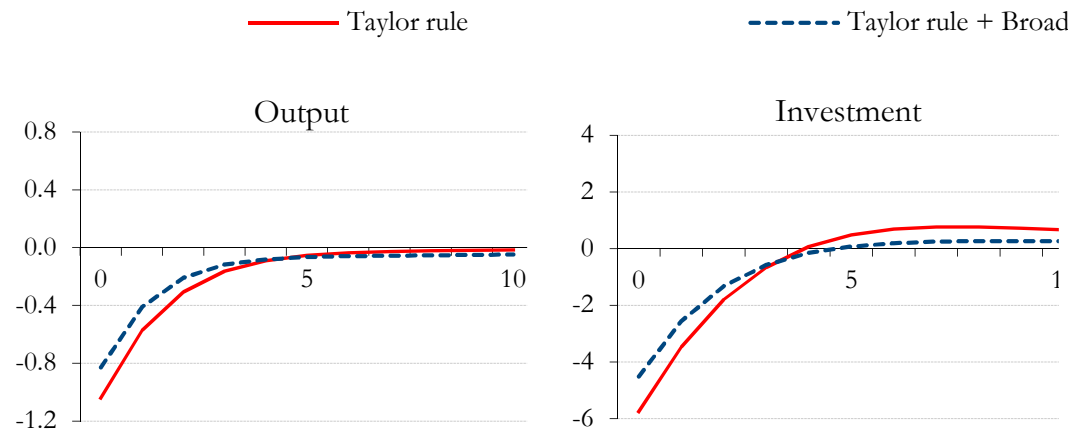

macroprudential policy
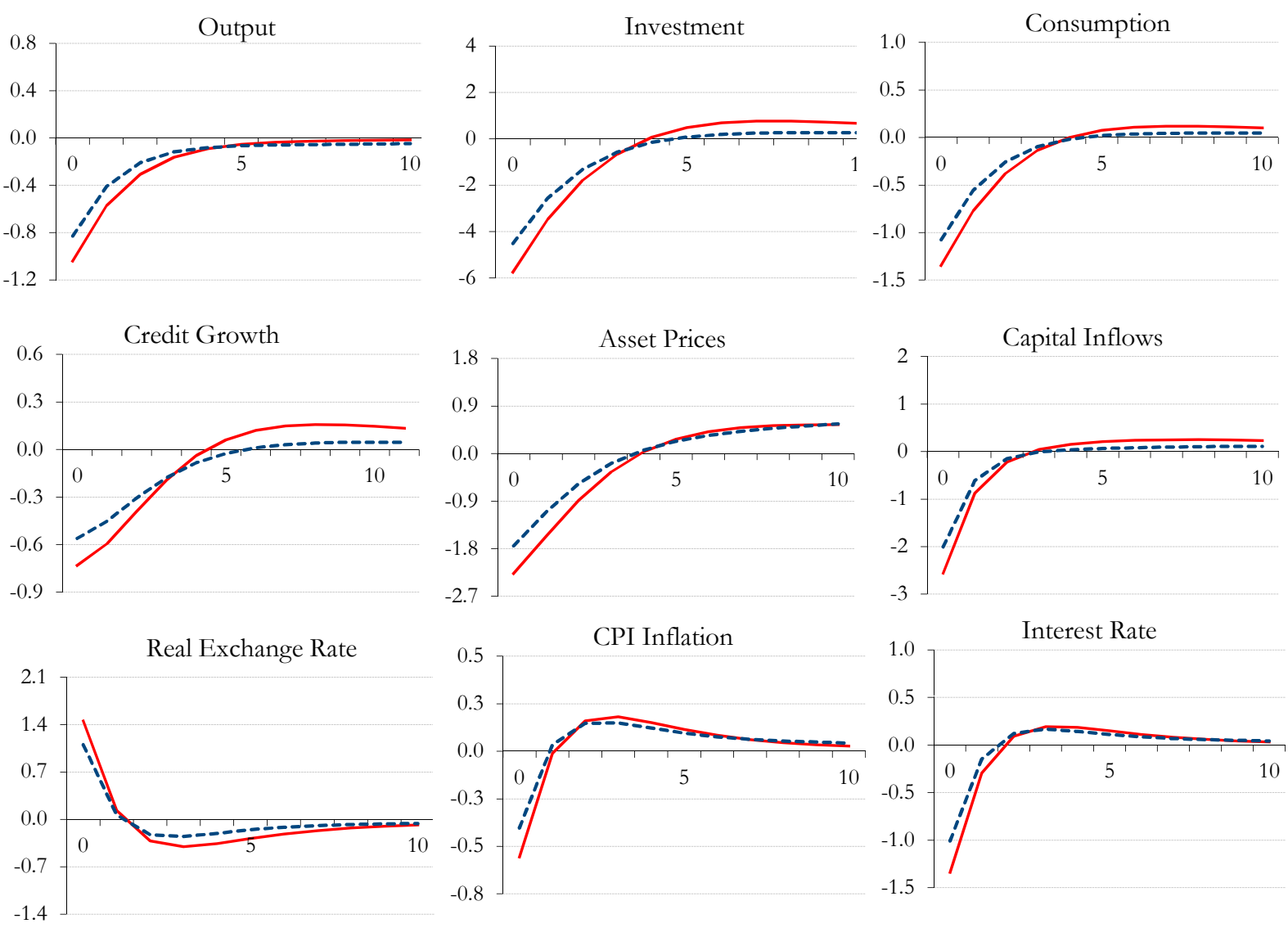

†The figures show the impact of a $1 \%$ negative shock to the perception of investors regarding the productivity of domestic entrepreneurs. The variables are presented as log-deviations from the steady state (except for interest rate), multiplied by 100 to have an interpretation of percentage deviations. 
Figure 2. A Negative Financial Shock: Taylor Rule and Taylor Rule with Credit Growth $†$ (percent deviations from the steady state)

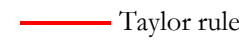

- - - Taylor rule with credit growth
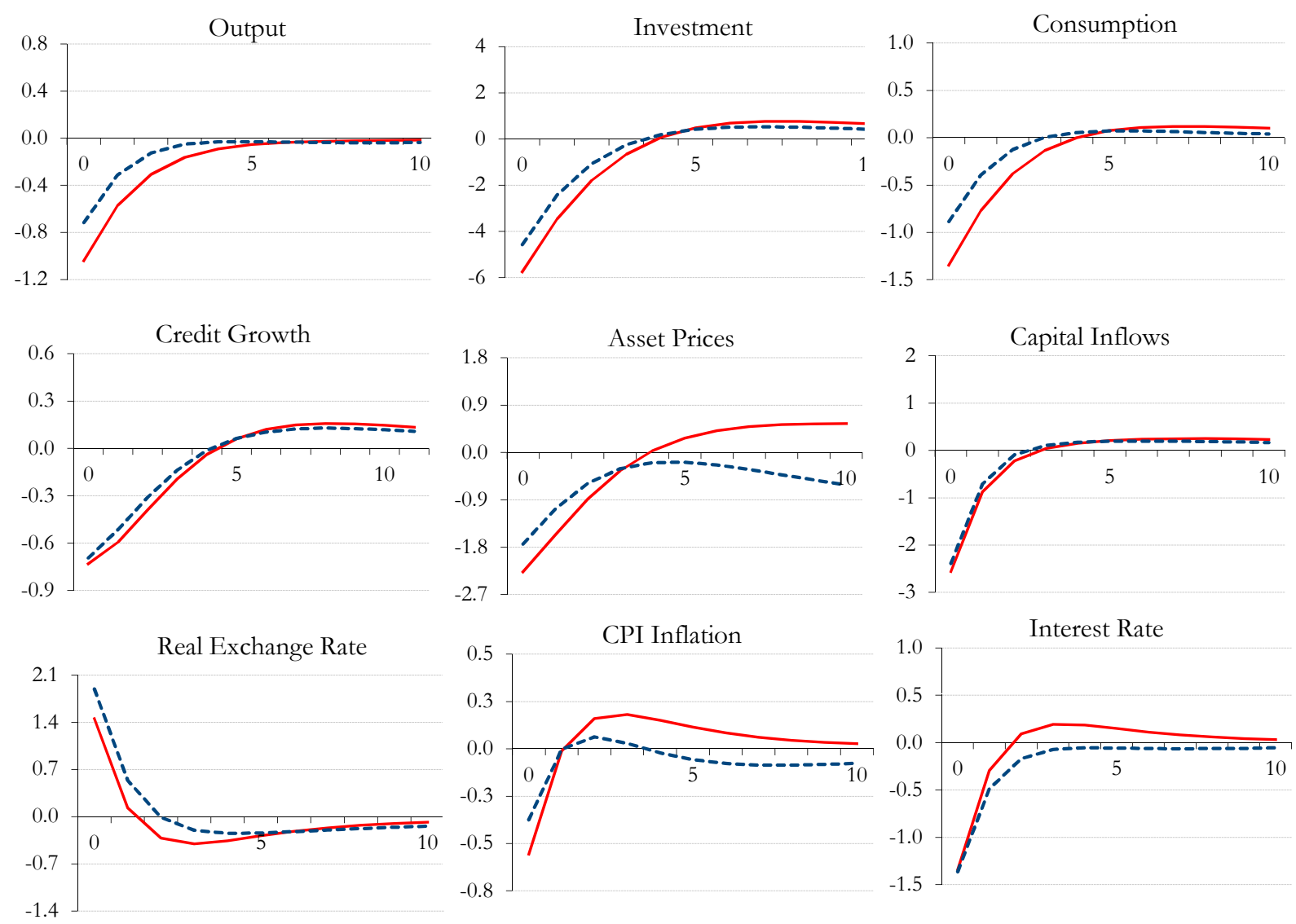

†The figures show the impact of a 1\% negative shock to the perception of investors regarding the productivity of domestic entrepreneurs. The variables are presented as log-deviations from the steady state (except for interest rate), multiplied by 100 to have an interpretation of percentage deviations. 
Figure 3. A Negative Productivity Shock: Taylor Rule and Macroprudential Policy† (percent deviations from the steady state)
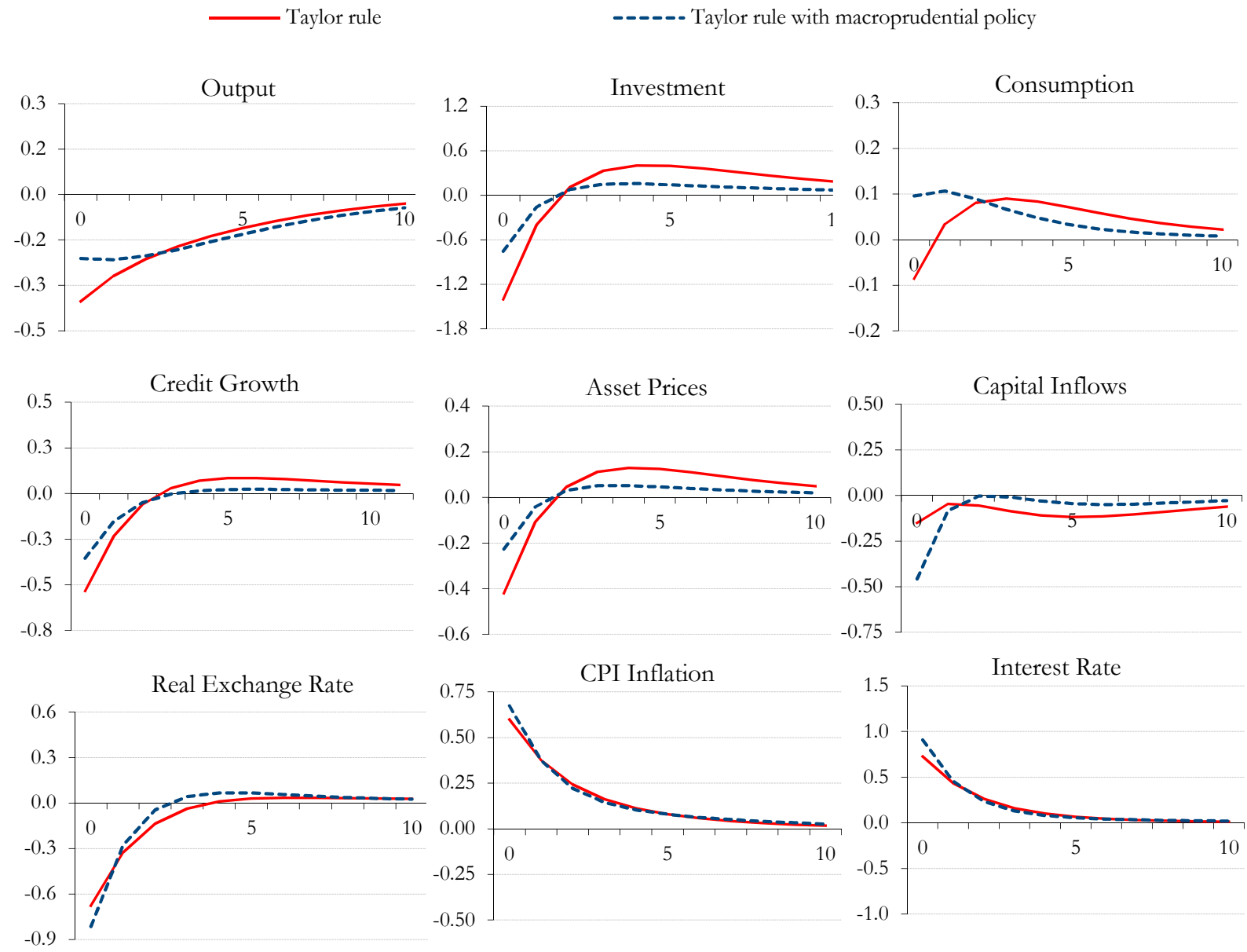

tThe figures show the impact of a $1 \%$ negative productivity shock. The variables are presented as log-deviations from the steady state (except for interest rate), multiplied by 100 to have an interpretation of percentage deviations. 
Figure 4. A Negative Productivity Shock: Taylor Rule and Taylor rule with Credit Growth $†$ (percent deviations from the steady state)

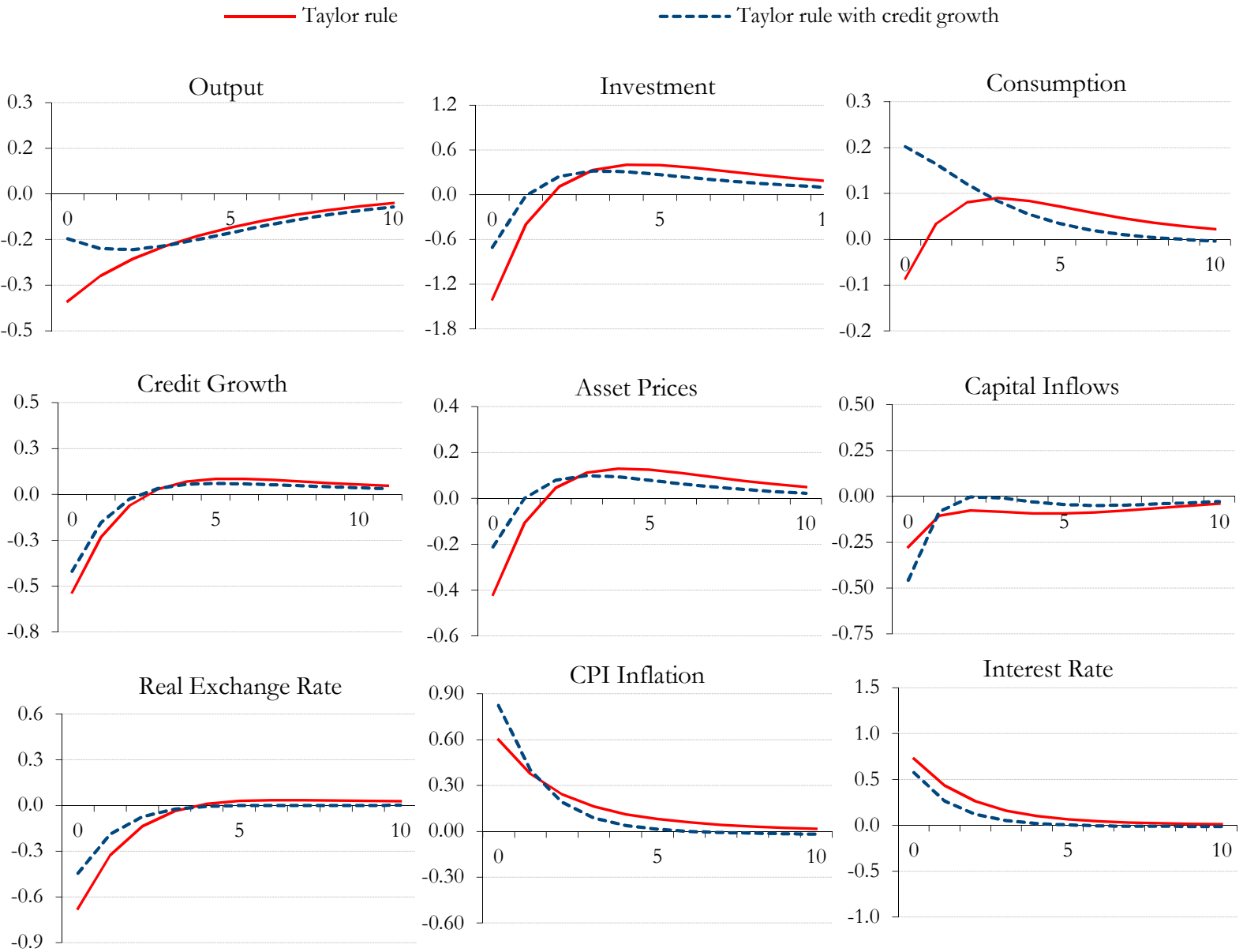

tThe figures show the impact of a $1 \%$ negative productivity shock. The variables are presented as log-deviations from the steady state (except for interest rate), multiplied by 100 to have an interpretation of percentage deviations. 